\title{
Antimicrobial Activity of Six Plant Extracts from the Brazilian Savanna on Periodontal Pathogens
}

\author{
Actividad Antimicrobiana de Seis Extractos de Plantas de la \\ Sabana Brasileña en Patógenos Periodontales
}

\begin{abstract}
Elerson Gaetti-Jardim Júnior*; Luis Fernando Landucci*; Omar Khalil Kidudsi Arafat" ${ }^{* *}$; Robson Varlei Ranieri"; Marcelle Marie Buso Ramos*; Francisco Isaak Nícolas Ciesielski*; Christiane Marie Schweitzer ${ }^{* * *}$ \& Ana Claudia Okamoto*
\end{abstract}

GAETTI-JARDIM Jr., E.; LANDUCCI, L. F.; ARAFAT, O. K. K.; RANIERI, R. V.; RAMOS, M. M. B.; CIESIELSKI, F. I. N.; SCHWEITZER, C. M. \& OKAMOTO, A. C. Antimicrobial activity of six plant extracts from the Brazilian savanna on periodontal pathogens. Int. J. Odontostomat., 5(3):249-256, 2011.

ABSTRACT: The extracts of plants from Brazilian savanna are currently used in popular medicine. This study evaluated the inhibitory activity of the alcoholic and aqueous extracts from savanna plants on periodontal bacteria. The minimal inhibitory concentrations were evaluated by the agar dilution method, using Wilkins-Chalgren agar. Antimicrobial activity of plants extracts on microbial biofilms was determined in microplates. Psidium cattleianum and Myracrodruon urundeuva extracts demonstrated significant inhibitory activity on all bacterial strains tested; alcoholic and aqueous extracts showed similar results. The extracts from these two species were able to inhibit both planktonic cells and microbial biofilm.

KEY WORDS: anaerobic bacteria, plant extracts, antimicrobial agents, periodontitis.

\section{INTRODUCTION}

Oral infectious diseases result from the loss of equilibrium between the host's immune response and virulence factors of the indigenous microbiota (Faveri et al., 2008; Feng \& Weinberg, 2006). Moreover, the control of the oral biofilm is a prerequisite to the health maintenance of the periodontal tissues and to balance the dynamic interactions between host and microbial factors (Bonifait \& Grenier, 2010; Madianos et al., 2005).

Several oral microorganisms have been studied as periodontopathogens. Aggregatibacter actinomycetemcomitans, Porphyromonas gingivalis, Prevotella intermedia, $P$. nigrescens and Fusobacterium nucleatum are particularly implicated because of the wide scope of their virulence factors and because of their interactions with a large variety of Gram-negative and Gram-positive bacteria in the development of periodontal diseases (Faveri et al.; Komiya Ito et al., 2010; Ledder et al., 2007; RodriguezGarcia et al., 2010). These microorganisms are often recovered in higher numbers from periodontal pockets with active attachment loss in relation to health gingival crevices (Ebersole et al., 2008; Tanner et al., 2007) and may establish complex ecological relationships among several oral bacteria and modulate host immune system and influence the outcome of the treatment (Bonifait \& Grenier; Jervøe-Storm et al., 2007; Kolenbrander et al., 2006).

Efficient and universal therapeutic approaches established for control of dental biofilm formation have not been developed. In addition, compromise of dental and periodontal tissues is a serious problem, especially in poor rural communities from developing countries, and urban populations with middle and low-income levels (Iwaki et al., 2006; Robertson et al., 2002). On the other hand, chemical compounds such as essential oils, chlorhexidine or antibiotics are commonly used during treatment of patients unable to maintain oral hygiene, mentally or physically handicapped, suffering from dental and/or surgical trauma, and with refractory,

\footnotetext{
* Department of Pathology and Clinical Propedeutics, Araçatuba Dental School, Universidade Estadual Paulista, Araçatuba, São Paulo, Brazil. "* Pharmacognosy and Phytotherapy Research Laboratory, São José do Rio Preto University, São Paulo, Brazil.

**Department of Mathematics, Engineering Faculty of Ilha Solteira, Universidade Estadual Paulista, Ilha Solteira, São Paulo, Brazil.
} 
GAETTI-JARDIM Jr., E.; LANDUCCI, L. F.; ARAFAT, O. K. K.; RANIERI, R. V.; RAMOS, M. M. B.; CIESIELSKI, F. I. N.; SCHWEITZER, C. M. \& OKAMOTO, A. C. Antimicrobial activity of six plant extracts from the Brazilian savanna on periodontal pathogens. Int. J. Odontostomat., 5(3):249-256, 2011.

aggressive or advanced periodontitis (Alviano et al., 2008; Gonzales et al., 2011). However, these chemicals frequently present several side effects when used for long periods (Baehni \& Takeuchi, 2003; Quirynen et al., 2006; Rodriguez-Garcia et al.), and RodriguezGarcia et al. suggested that the search for natural phytochemicals isolated from plants used as traditional medicine or new biomaterials are considered good alternatives to oral hygiene.

It is estimated that one-third to one-half of Americans practice some form of alternative medicine, with use of natural or herbal health care products, especially dentifrices (Lee et al., 2004). In Brazil, the biodiversity observed in the tropical forests and savannas offers a wide variety of pharmacological and therapeutic compounds with intense activity on microbial biofilms. Still, only a fraction of their biological diversity as a source of drugs has been characterized and evaluated. While the "knowledge-bank" of Brazilian popular medicine is large, most of the information contained therein has not been verified by scientific studies, and many plants have received little or no attention (de Lima et al., 2006). Moreover, there is a popular misconception that natural medicines have no side effects, are totally safe and indeed harmless (de Lima et al.).

Plants such as Ficus enormis, Myracrodruon urundeuva, Patagonula americana, Piptocarpha rotundifolia, Psidium cattleianum and Maytenus ilicifolia are employed by native Brazilians and rural populations living in the highlands of Central, Northern, Northeastern Brazilian regions and surrounding the borders of Amazon tropical forest as anti-septic, antiinflammatory and anti-diarrhea medicine (Monteiro et al., 2006). Thus, the goal of this study was to evaluate the antimicrobial properties of the crude extracts of these plants from the Brazilian savanna using reference strains of four periodontal bacteria and fresh clinical isolates of Fusobacterium nucleatum and Porphyromonas gingivalis.

\section{MATERIAL AND METHOD}

Bacterial Strains, Growth Conditions and Culture Medium. The bacteria used in this study were Fusobacterium nucleatum ATCC 25586, Porphyromonas gingivalis ATCC 33277 , Prevotella intermedia ATCC 2564, Aggregatibacter actinomycetemcomitans ATCC 33384, 10 clinical isolates of $P$. gingivalis and $10 F$. nucleatum from periodontal pockets of patients with chronic periodontitis. Bacteria were grown in brain heart infusion broth (BHI - Difco, USA) supplemented with yeast extract $(0.5 \%)$, hemin $(5 \mu \mathrm{g} / \mathrm{ml})$ e menadione $(1 \mu \mathrm{g} /$ $\mathrm{ml})$ and incubated anaerobically (90\% N2 / 10\% CO2), at $37^{\circ} \mathrm{C}$ for 72 hours.

Plant Extracts. Leaf extract from Ficus enormis (Mart. ex Miq.), Myracrodruon urundeuva (Allemao), Patagonula americana (Allemao), Piptocarpha rotundifolia (Baker), Psidium cattleianum (Sabine) and stem extracts from Maytenus ilicifolia (Mart. ex Reissek) were grown at the São Paulo State University- UNESP, São Paulo, Brazil, in natural conditions, without addition of chemical compounds such as chemical fertilizers, pesticides and insecticides. Plants were washed threetimes in deionized water, allowed to dry in a dark room (initially at room temperature for 30 days and then at $37^{\circ} \mathrm{C}$ for 15 days) and ground until a thin powder was achieved. Plants were harvested in January 2006 and the voucher specimen is deposited at the Herbarium of Pharmacognosy and Phytotherapy Research Laboratory, UNIRP, São Paulo, Brazil.

Alcoholic extracts were prepared by adding $25 \mathrm{~g}$ of plant powder to $125 \mathrm{ml}$ of $80 \%$ ethanol. During 12 days, the mixtures were vigorously shaken (5x/day, 3 min each). To extract water-soluble chemical compounds, $25 \mathrm{~g}$ of the ground leaves were decocted in $125 \mathrm{ml}$ of deionized water for $5 \mathrm{~min}$ at $100^{\circ} \mathrm{C}$, at $55^{\circ} \mathrm{C}$ for an additional $1 \mathrm{~h}$ and at room temperature for 3 days. The extracts were filter-sterilized using a $0.22 \mu \mathrm{m}$ cellulose membrane (Millipore). Both alcoholic and aqueous extracts were allowed to evaporate at $37^{\circ} \mathrm{C}$ to achieve final concentration of $150 \mathrm{mg} / \mathrm{ml}$. The extracts were prepared immediately before use to avoid oxidation or were stored at $-40^{\circ} \mathrm{C}$ during 10 days.

Determination of the minimal inhibitory concentrations (MICs). MICs were determined by agar dilution method, following the CLSI recommendations. The agar dilution tests were performed using Wilkins-Chalgren agar supplemented with horse blood $(5 \%)$, hemin $(5 \mu \mathrm{g} / \mathrm{ml})$ and menadione $(1 \mu \mathrm{g} / \mathrm{ml})$. Media containing two-fold serial dilutions of plant extracts ranging from $0.125 \mathrm{mg} / \mathrm{ml}$ to $128 \mathrm{mg} / \mathrm{ml}$ were inoculated with a Steers replicator resulting (1.5 $x 105 \mathrm{CFU}$ (spot). All plates were incubated anaerobically at $37^{\circ} \mathrm{C}$ for $48 \mathrm{~h}$. MIC was defined as the lowest concentration that was able to inhibit bacterial growth. 
GAETTI-JARDIM Jr., E.; LANDUCCI, L. F.; ARAFAT, O. K. K.; RANIERI, R. V.; RAMOS, M. M. B.; CIESIELSKI, F. I. N.; SCHWEITZER, C. M. \& OKAMOTO, A. C. Antimicrobial activity of six plant extracts from the Brazilian savanna on periodontal pathogens. Int. J. Odontostomat., 5(3):249-256, 2011.

Determination of the minimal bactericidal concentration (MBC). In order to determine the MBC, the microorganisms were also submitted to evaluation of their susceptibilities to the plant extracts by broth dilution method. In these tests, extracts were added to $\mathrm{BHI}$ broth supplemented with $0.5 \%$ yeast extract, hemin $(5 \mu \mathrm{g} / \mathrm{ml})$ and menadione $(1 \mu \mathrm{g} / \mathrm{ml})$ containing a bacterial inoculum of $1.5 \times 105 \mathrm{CFU} / \mathrm{ml}$. The concentrations used ranged from $0.125 \mathrm{mg} / \mathrm{ml}$ to $128 \mathrm{mg} / \mathrm{ml}$. MIC was defined as above after anaerobic incubation at $37^{\circ} \mathrm{C}$ for $72 \mathrm{~h}$.

Aliquots of $100 \mathrm{ml}$ from broth with no growth were plated onto $\mathrm{BHI}$ agar supplemented and incubated at $37^{\circ} \mathrm{C}$ for $48 \mathrm{~h}$. The MBC was defined as the highest dilution where no bacterial growth was recorded. In all tests, sterile $0.85 \%$ phosphate buffered saline (PBS) and broth without plant extracts were use as controls.

Time-kill Curve. Time-kill curves of extracts from $M$. urundeuva and $P$. cattleianum were established for $P$. gingivalis ATCC 33277 and $F$. nucleatum ATCC 25586. Initially, $105 \mathrm{CFU} / \mathrm{ml}$ were incubated in $\mathrm{BHI}$ broth. The plants extracts were added at a final concentration corresponding to their MBC. A bacterial suspension in PBS was used as control. At different time intervals, $100 \mathrm{ml}$ of the samples were removed, and plated on blood agar. Colonies were counted after incubation in anaerobiosis at $37^{\circ} \mathrm{C}$ for $72 \mathrm{~h}$.

Inhibitory activity of plant extracts on biofilm. Dualspecies biofilms were used to test the inhibitory activity of plant extracts. The biofilms were always composed by Fusobacterium nucleatum ATCC 25586 plus another microorganism ( $P$. gingivalis ATCC 3327, $A$. actinomycetemcomitans ATCC 33384 or $P$. intermedia ATCC 2564). F. nucleatum was selected because of its ability to improve bacterial adhesion to polystyrene wells and by its complementary metabolic traits with the other strains. The additional strains were selected due to their relationship with the most frequent anaerobic infections in the oral cavity and their ability to build biofilm structures.

All tested bacteria were grown in $\mathrm{BHI}$ broth supplemented with hemin $(5 \mu \mathrm{g} / \mathrm{ml})$, menadione $(1 \mu \mathrm{g} /$ $\mathrm{ml}$ ) and glucose (1\%). Initially, $200 \mathrm{ml}$ of $F$. nucleatum ATCC 25586 containing 106 CFU were inoculated in sterile 6 -wells polystyrene microplates and incubated anaerobically for $2 \mathrm{~h}$ at $37^{\circ} \mathrm{C}$. Next, $200 \mu \mathrm{l}$ of bacterial suspension of the second bacteria (giving an inoculum of $106 \mathrm{CFU}$ ) and $2 \mathrm{ml}$ of supplemented $\mathrm{BHI}$ broth were added to each well and incubated at $37^{\circ} \mathrm{C}$ for 7 days. The medium was refreshed daily. After 7 days, the biofilm could be observed as a thin membrane recovering the plate wells.

Dehydrated plant extract was mixed with $1500 \mathrm{ml}$ of supplemented $\mathrm{BHI}$ broth (to a final concentration of $100 \mathrm{mg} / \mathrm{ml}$ ) and added to the microplates to cover up all microbial growth. The biofilm was incubated in an anaerobic chamber for 5, 10, 20 minutes, $1 \mathrm{~h}-8 \mathrm{~h}$, and $24 \mathrm{~h}$ at $37^{\circ} \mathrm{C}$. Next, the medium from each well was removed and bacterial biofilms were harvested by using a spatula. The cells were vigorously homogenized for 15 seconds in 3ml of VMG I solution (Möller, 1966) and submitted to 10 -fold serial dilutions in VMG I. Then, $0.1 \mathrm{ml}$ of each dilution was plated on blood agar, which was incubated anaerobically at $37^{\circ} \mathrm{C}$ for $3-4$ days.

After incubation, colonies were counted. The inhibitory activity was considered to be $90 \%$ reduction of viable bacteria compared to the control (PBS). Tests were performed in triplicate and the results were expressed as the time required to reduce microbial survival by $90 \%$ in relation to control. In addition, clinical isolates of $F$. nucleatum and $P$. gingivalis were also evaluated.

Statistical analysis. Statistical significance was determined by using an analysis of variance (SPSS 11.0 for Windows). Fisher's exact test was applied to contingency tables to compare the extract effectiveness of $M$. urundeuva and $P$. cattleianum on the bacterial biofilm. $P<0.05$ values were considered statistically significant.

\section{RESULTS AND DISCUSSION}

The MIC and MBC values of six plant extracts against four reference strains are shown in Table I. The antimicrobial activity of $M$. urundeuva and $P$. cattleianum in agar or broth dilution methods was not significantly different. These extracts showed high activity against strains tested, with MIC values ranging from $0.25 \mathrm{mg} / \mathrm{ml}$ up to $0.5 \mathrm{mg} / \mathrm{ml}$.

Alcoholic and aqueous extracts from $P$. americana, $M$. ilicifolia and $P$. rotundifolia did not exhibit antimicrobial activity on planktonic microorganisms, while alcoholic extract from $F$. enormis was more active than aqueous extract against planktonic bacteria. No significant differences between aqueous or alcoholic extracts from $M$. urundeuva and $P$. cattleianum were observed. MBC was 2 up to 16 fold higher than MIC 
GAETTI-JARDIM Jr., E.; LANDUCCI, L. F.; ARAFAT, O. K. K.; RANIERI, R. V.; RAMOS, M. M. B.; CIESIELSKI, F. I. N.; SCHWEITZER, C. M. \& OKAMOTO, A. C. Antimicrobial activity of six plant extracts from the Brazilian savanna on periodontal pathogens. Int. J. Odontostomat., 5(3):249-256, 2011.

values. This same pattern could be observed to MIC and MBC values of plant extracts on clinical isolates of $P$. gingivalis and F. nucleatum (Table II). These clinical isolates showed a broad scope of extracts susceptibility, but in general their susceptibility was reduced in comparison to the reference strains in planktonic or biofilm conditions.

Time-kill curve of the alcoholic and aqueous extracts from $P$. cattleianum and $M$. urundeuva showed similar results for both $P$. gingivalis ATCC 33277 and $F$. nucleatum ATCC $25586(P=0.7189)$. A log reduction of the planktonic bacterial inoculum was achieved within 60 min after the extracts were added (Fig. 1).

The antimicrobial activities of the extracts were similar against all the bacterial associations used in the biofilms $(P=0.3427)$. The biofilm produced by association of $F$. nucleatum ATCC 25586 and $A$. actinomycetemcomitans ATCC 33384 was lightly more

Table I. Antimicrobial activity of alcoholic and aqueous plant extracts against four periodontal reference strains.

\section{$\operatorname{MIC} / \mathrm{MBC}(\mathrm{mg} / \mathrm{ml})$}

\begin{tabular}{lcccc} 
Plant extract & $\begin{array}{c}\text { A. } \\
\text { actinomycetemcomitans } \\
\text { ATCC 33384 }\end{array}$ & $\begin{array}{c}\text { F. nucleatum } \\
\text { ATCC 25586 }\end{array}$ & $\begin{array}{c}\boldsymbol{P} \text {. gingivalis } \\
\text { ATCC 33277 }\end{array}$ & $\begin{array}{c}\boldsymbol{P} \text {. intermedia } \\
\text { ATCC 2564 }\end{array}$ \\
\hline Alcoholic extract & & & & \\
F. enormis & $32 / 128$ & $16 / 64$ & $8 / 128$ & $8 / 128$ \\
M. urundeuva & $1 / 8$ & $0.5 / 8$ & $0.5 / 16$ & $1 / 16$ \\
P. cattleianum & - & $0.5 / 4$ & $0.5 / 8$ & $1 / 8$ \\
Aqueous extract & & & & $64 / 128$ \\
F. enormis & $64 />128$ & $32 />128$ & $32 />128$ & $1 / 16$ \\
M. urundeuva & $2 / 8$ & $0.5 / 8$ & $0.5 / 16$ & $1 / 8$ \\
P. cattleianum & $2 / 4$ & $1 / 4$ & $0.5 / 8$ & \\
\hline
\end{tabular}

Table II. Antimicrobial activity of alcoholic and aqueous plant extracts against clinical isolates of Fusobacterium nucleatum and Porphyromonas gingivalis.

\begin{tabular}{|c|c|c|c|}
\hline \multirow{2}{*}{$\begin{array}{l}\text { Microorganism (n) plant } \\
\text { extracts }\end{array}$} & \multicolumn{3}{|c|}{ MIC/MBC (mg/ml) } \\
\hline & Range & $\mathrm{MIC}_{50} / \mathrm{MBC}_{50}$ & $\mathrm{MIC}_{90} / \mathrm{MBC}_{90}$ \\
\hline \multicolumn{4}{|c|}{ Fusobacterium nucleatum (10) } \\
\hline \multicolumn{4}{|l|}{ Aqueous extract } \\
\hline F. enormis & $16-128 / 16>128$ & $32 / 128$ & $128 />128$ \\
\hline M. urundeuva & $2-32 / 8-64$ & $2 / 16$ & $8 / 64$ \\
\hline P. cattleianum & $1-32 / 4-64$ & $2 / 8$ & $8 / 32$ \\
\hline \multicolumn{4}{|l|}{ Alcoholic extract } \\
\hline F. enormis & $8-128 / 16-128$ & $32 / 64$ & $64 / 128$ \\
\hline M. urundeuva & $1-32 / 8-64$ & $2 / 16$ & $8 / 64$ \\
\hline P. cattleianum & $1-32 / 4-64$ & $2 / 8$ & $8 / 32$ \\
\hline \multicolumn{4}{|c|}{ Porphyromonas gingivalis (10) } \\
\hline \multicolumn{4}{|l|}{ Aqueous extract } \\
\hline F. enormis & $8-128 / 16-128$ & $32 / 128$ & $64 / 128$ \\
\hline M. urundeuva & $2-32 / 4-64$ & $2 / 16$ & $8 / 64$ \\
\hline P. cattleianum & $1-32 / 2-64$ & $2 / 8$ & $8 / 64$ \\
\hline \multicolumn{4}{|l|}{ Alcoholic extract } \\
\hline F. enormis & $8-128 / 16-128$ & $32 / 64$ & $64 / 128$ \\
\hline M. urundeuva & $1-32 / 8-32$ & $2 / 16$ & $8 / 32$ \\
\hline P. cattleianum & $1-32 / 4-32$ & $2 / 8$ & $8 / 32$ \\
\hline
\end{tabular}


GAETTI-JARDIM Jr., E.; LANDUCCI, L. F.; ARAFAT, O. K. K.; RANIERI, R. V.; RAMOS, M. M. B.; CIESIELSKI, F. I. N.; SCHWEITZER, C. M. \& OKAMOTO, A. C. Antimicrobial activity of six plant extracts from the Brazilian savanna on periodontal pathogens. Int. J. Odontostomat., 5(3):249-256, 2011.

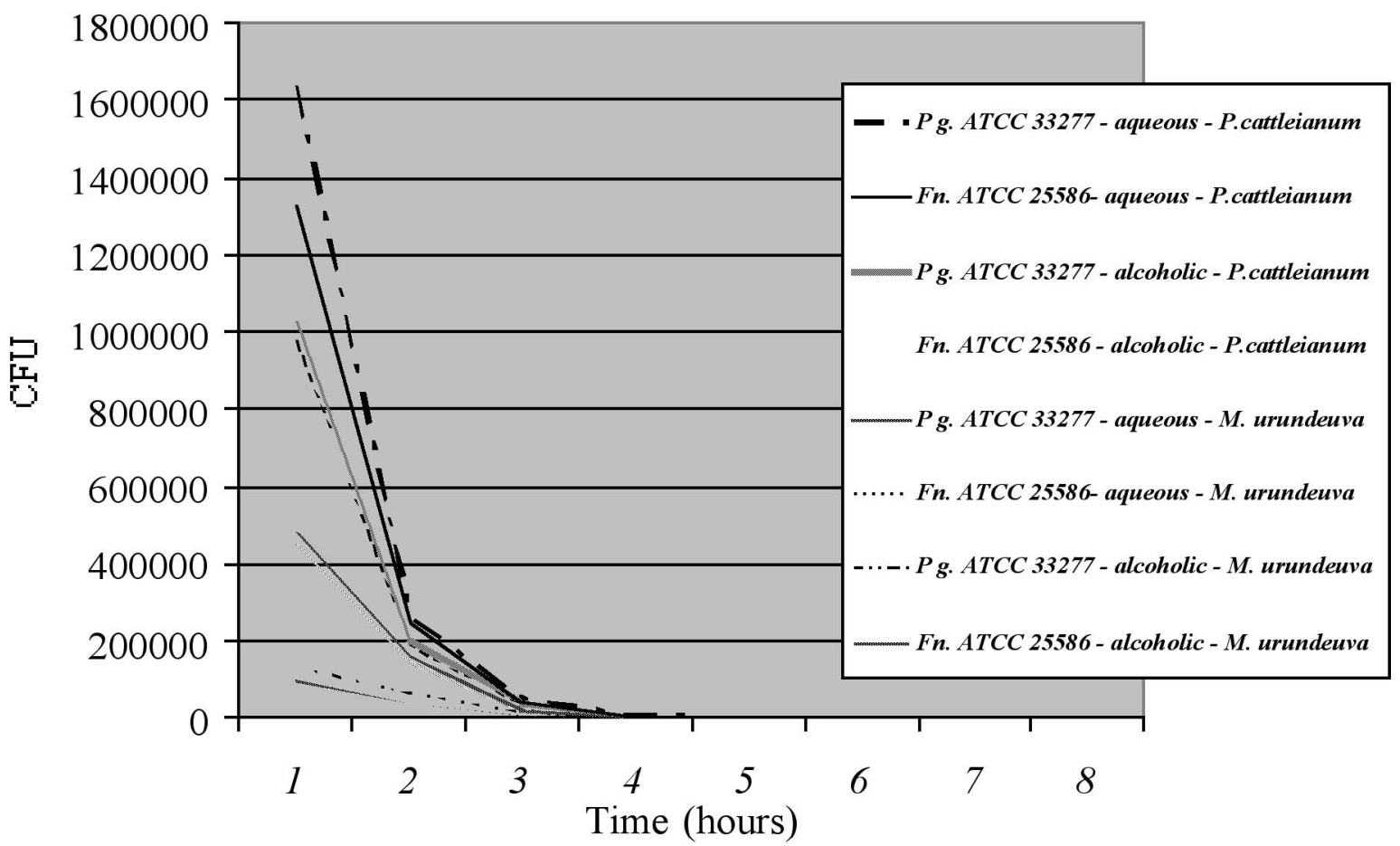

Fig. 1. Time-kill curve to P. gingivalis ATCC $33277(\mathrm{Pg})$ and F. nucleatum ATCC $25586(\mathrm{Fn})$ for the alcoholic and aqueous extracts from $P$. cattleianum $(\mathrm{A})$ and $M$. urundeuva $(\mathrm{B})$.

resistant to the alcoholic and aqueous extracts action from M. urundeuva and $P$. cattleianum. In the biofilm assays, the log bacterial reduction was achieved within 30-60 min after contact with alcoholic extracts and within 60 min with aqueous extracts $(P=0.0023)$. These results were also observed when clinical isolates of $F$. nucleatum and $P$. gingivalis were evaluated.

Natural medicines and drugs are widely used by populations living near the margins of the Amazon forest and in the savanna of the Central, Northeastern, and Northern Brazil, where public and private medical care are scarce, and Alviano et al. and RodriguezGarcia et al. related that the phytochemicals isolated from plants used as traditional medicine are a good alternative to oral hygiene. Studies have shown that in South America folk medicines provide a wide range of alcoholic or aqueous extracts with antimicrobial properties (de Lima et al.; Sartoratto et al., 2004), but few studies testing natural extracts as antimicrobials against oral Gram-negative strict and facultative anaerobes are observed (Baehni \& Takeuchi; Iwaki et al.; Nagata et al., 2006).

M. urundeuva is a common plant used as natural medicine for rural populations from Brazilian savanna due to its anti-ulcerogenic, analgesic and antiinflammatory properties (de Albuquerque et al., 2007; Rao et al., 1987). Psidium spp. is native to tropical America and it has been used to treat scurvy in Asia and Africa, diarrhea in Mexico, cough and pulmonary diseases in Bolivia and Egypt, and as an antiinflammatory and hemostatic agent in China due to its composition of phenols, triterpenes and essential oils, such as eugenol (Jaiarj et al., 1999; Lozoya et al., 1994).

While the molecular and cellular processes involved in the pathogenesis of the periodontitis are being studied, efficient therapeutic strategies have not yet been established for all patients, particularly for populations living in isolated and poor areas from developing countries (Alviano et al.; Komiya Ito et al.; Iwaki et al.). These communities use plant extracts for the treatment of periodontal diseases and other infections, but the effectiveness of these natural products has not been scientifically established (Alviano et al.). The importance of scientifically test empirical preparations is supported by our study: from the six plants tested, three (Patagonula americana, Piptocarpha rotundifolia, and Maytenus ilicifolia) did not show any antimicrobial activity, and one ( $F$. enormis) just evidenced some antimicrobial activity. 
On the other hand, our results show that extracts obtained from $P$. cattleianum and $M$. urundeuva displayed good activity against the four oral reference strains and all clinical isolates, in both planktonic and biofilm conditions. These findings are very interesting, since natural extracts showing activity against oral Gram-negative anaerobes and microaerophiles are rarely described in literature (Bakri \& Douglas, 2005; Iwaki et al.). Particularly, A. actinomycetemcomitans possesses morphological characteristics that may explain the higher resistance to the extracts observed in the present study. Its membrane vesicles-like folds may form a barrier and delay or minimize the access of the plant extracts to the periplasmic and cytoplasmic spaces and in addition the outer membrane vesicles can contain proteases that inactive the plant extracts (Duchesne et al., 1995; Mashburn-Warren \& Whiteley, 2006).

Exposition of cariogenic bacteria to sub-lethal concentrations of $P$. cattleianum extract produced a significant reduction in the abundance of proteins essential for RNA synthesis, protein synthesis and energy metabolism, with especial distinction to enzymes that are required for glycolysis and lactic acid production (Brighenti et al., 2008). However, the effects of the extracts on physiology of anaerobes remain unclear. Studies must be performed to evaluate their effects at low concentrations and the mechanism of bacterial killing at high concentrations.

A new drug to be used as effective therapy for periodontitis must especially be active against biofilm, since this structure is the natural model of arrangement of microorganisms in oral cavity (Alviano et al.). There are evidences that biofilm microstructure represents a key determinant of biofilm growth, physiology, species diversity, and susceptibility to antimicrobial strategies (Singleton et al., 1997). Studies have shown that cells grown in biofilm may delay or prevent the action of chemically active compounds (Alviano et al.; Bakri \& Douglas).

A general view concerning the formation of dental biofilm suggests that $F$. nucleatum initially colonizes the tooth and gingival surfaces to form the substrate onto which later colonizers, such as periodontopathogens can adhere and then migrate to deeper periodontal pockets for colonization. In this process, a synergistic relationship between fusobacteria and these Gram-negative rods could interfere in the susceptibility to antimicrobial drugs and in the expression of virulence genes (Kolenbrander et al.). In this study, individually Gram-negative bacteria produce a weak biofilm, but when $F$. nucleatum was associated to the strains, a robust biofilm was produced.

\section{CONCLUSION}

In summary, we demonstrated that extracts obtained from $P$. cattleianum and $M$. urundeuva displayed good activity against the microorganisms tested both in planktonic and biofilm conditions. Further studies to characterize the aqueous and alcoholic extracts of $P$. cattleianum and $M$. urundeuva and their usefulness as source of new components in mouthwashes and toothpastes must be performed. In vivo studies to study the antimicrobial mechanisms and toxicity of these extracts in rats and monkeys oral and intestinal microbiota are currently underway.

\section{ACKNOWLEDGEMENTS}

The authors thank, José Marcelo Tramarim, Miriam Regina Mouro Ferraz Lima and Elaine Cristina Francischini Ferreira for their technical support. This study was supported by grants of State of São Paulo Research Foundation (FAPESP - Grant \#01/09783-0 and 03/12763-7).

GAETTI-JARDIM Jr., E.; LANDUCCI, L. F.; ARAFAT, O. K. K.; RANIERI, R. V.; RAMOS, M. M. B.; CIESIELSKI, F. I. N.; SCHWEITZER, C. M. \& OKAMOTO, A. C. Actividad antimicrobiana de seis extractos de plantas de la sabana brasileña en patógenos periodontales. Int. J. Odontostomat., 5(3):249-256, 2011.

RESUMEN: Los extractos de las plantas de la sabana brasileña actualmente se utilizan en la medicina popular. Este estudio evaluó la actividad inhibitoria de los extractos alcohólicos y acuosos de plantas de la sabana en bacterias periodontales. Las concentraciones inhibitorias mínimas fueron evaluados por el método de dilución en agar, utilizando agar Wilkins-Chalgren. La actividad antimicrobiana de los extractos de plantas en las biopelículas microbianas se determinó en microplacas. Los extractos de Psidium cattleianum y Myracrodruon urundeuva demostraron una importante actividad inhibitoria sobre todas las cepas bacterianas probadas, extractos alcohólicos y acuosos mostraron resultados similares. Los extractos de estas dos especies fueron capaces de inhibir las células planctónicas y biofilm microbiano.

PALABRAS CLAVE: bacterias anaerobias, extractos de plantas, agentes antimicrobianos, periodontitis. 
GAETTI-JARDIM Jr., E.; LANDUCCI, L. F.; ARAFAT, O. K. K.; RANIERI, R. V.; RAMOS, M. M. B.; CIESIELSKI, F. I. N.; SCHWEITZER, C. M. \& OKAMOTO, A. C. Antimicrobial activity of six plant extracts from the Brazilian savanna on periodontal pathogens. Int. J. Odontostomat., 5(3):249-256, 2011.

\section{REFERENCES}

Alviano, W. S.; Alviano, D. S.; Diniz, C. G.; Antoniolli, A. R.; Alviano, C. S.; Farias, L. M.; Carvalho, M. A.; Souza, M. M. \& Bolognese, A. M. In vitro antioxidant potential of medicinal plant extracts and their activities against oral bacteria based on Brazilian folk medicine. Arch. Oral Biol., 53:545-52, 2008.

Baehni, P. C. \& Takeuchi, Y. Anti-plaque agents in the prevention of biofilm-associated oral diseases. Oral Dis., 9:23-9, 2003.

Bakri, I. M. \& Douglas, C. W. Inhibitory effect of garlic extract on oral bacteria. Arch. Oral Biol., 50:645-51, 2005.

Bonifait, L. \& Grenier, D. Cranberry polyphenols: potential benefits for dental caries and periodontal disease. J. Can. Dent. Assoc., 76:a130, 2010.

Brighenti, F. L.; Luppens, S. B.; Delbem, A. C.; Deng, D. M.; Hoogenkamp, M. A.; Gaetti-Jardim, E. Jr.; Dekker, H. L.; Crielaard, W. \& ten Cate, J. M. Effect of Psidium cattleianum leaf extract on Streptococcus mutans viability, protein expression and acid production. Caries Res., 42:148-54, 2008.

de Albuquerque, U. P.; Monteiro, J. M.; Ramos, M. A. \& Amorim, E. L. C. Medicinal and magic plants from a public market in northeastern Brazil. J. Ethnopharmacol., 110:76-91, 2007.

de Lima, M. R.; de Souza Luna, J.; dos Santos, A. F.; de Andrade, M. C.; Sant'Ana, A. E.; Genet, J. P.; Marquez, B.; Neuville, L. \& Moreau, N. Anti-bacterial activity of some Brazilian medicinal plants. J. Ethnopharmacol., 105:13747, 2006.

Duchesne, P.; Grenier, D. \& Mayrand, D. Demonstration of adherence properties of Porphyromonas gingivalis outer membrane vesicles using a new microassay. Oral Microbiol. Immunol., 10:76-80, 1995.

Ebersole, J. L.; Holt, S. C.; Hansard, R. \& Novak, M. J. Microbiologic and immunologic characteristics of periodontal disease in Hispanic Americans with type 2 diabetes. J. Periodontol., 79:637-46, 2008.

Faveri, M.; Mayer, M. P.; Feres, M.; Figueiredo, L. C.; Dewhirst, F. E. \& Paster, B. J. Microbiological diversity of generalized aggressive periodontitis by $16 \mathrm{~S}$ rRNA clonal analysis. Oral Microbiol. Immunol., 23:112-8, 2008.

Feng, Z. \& Weinberg, A. Role of bacteria in health and disease of periodontal tissues. Periodontol. 2000, 40:50-76, 2006.

Gonzales, J. R.; Harnack, L.; Schmitt-Corsitto, G.; Boedeker, R. H.; Chakraborty, T.; Domann, E. \& Meyle,
J. A novel approach in the use of subgingival controlledrelease delivery of chlorhexidine in chronic periodontitis: a randomized clinical trial. J. Periodontol., 82:1131:9, 2011.

Iwaki, K.; Koya-Miyata, S.; Kohno, K.; Ushio, S. \& Fukud, S. Antimicrobial activity of Polygonum tinctorium Lour: extract against oral pathogenic bacteria. J. Nat. Med., 60:121-5, 2006.

Jaiarj, P.; Khoohaswan, P.; Wongkrajang, Y.; Peungvicha, P.; Suriyawong, P.; Saraya, M. L. \& Ruangsomboon, O. Anticough and antimicrobial activities of Psidium guajava Linn leaf extract. J. Ethnopharmacol., 67:203-12, 1999.

Jervøe-Storm, P. M.; AIAhdab, H.; Semaan, E.; Fimmers, R. \& Jepsen, S. Microbiological outcomes of quadrant versus full-mouth root planing as monitored by real-time PCR. J. Clin. Periodontol., 34:156-63, 2007.

Kolenbrander, P. E.; Palmer, R. J. Jr.; Rickard, A. H.; Jakubovics, N. S.; Chalmers, N. I. \& Diaz, P. I. Bacterial interactions and successions during plaque development. Periodontol. 2000, 42:47-79, 2006.

Komiya Ito, A.; Ishihara, K.; Tomita, S.; Kato, T. \& Yamada, $\mathrm{S}$. Investigation of subgengival profile or periodontopathic bacteria using polymerase chain reaction. Bull. Tokyo Dent. Coll., 51:139-44, 2010.

Ledder, R. G.; Gilbert, P.; Huws, S. A.; Aarons, L.; Ashley, M. P.; Hull, P. S. \& McBain, A. J. Molecular analysis of the subgingival microbiota in health and disease. Appl. Environ. Microbiol., 73:516-23, 2007.

Lee, S. S.; Zhang, W. \& Li, Y. The antimicrobial potential of 14 natural herbal dentifrices: results of an in vitro diffusion method study. J. Am. Dent. Assoc., 135:1133-41, 2004.

Lozoya, X.; Meckes, M.; Abou-Zaid, M.; Tortoriello, J.; Nozzolillo, C. \& Amason, J. T. Quercetin glycosides in Psidium guajava Linn. leaves and determination of spasmolytic principle. Arch. Med. Res., 25:11-5, 1994.

Madianos, P. N.; Bobetsis, Y. A. \& Kinane, D. F. Generation of inflammatory stimuli: how bacteria set up inflammatory responses in the gingiva. J. Clin. Periodontol., 32:57-71, 2005.

Mashburn-Warren, L. M. \& Whiteley, M. Special delivery: vesicle trafficking in prokaryotes. Mol. Microbiol., 61:83946, 2006.

Möller, A. J. Microbial examination of root canals and periapical tissues of human teeth: methodological studies. Odontol. Tidskr, 74:1-138, 1966. 
GAETTI-JARDIM Jr., E.; LANDUCCI, L. F.; ARAFAT, O. K. K.; RANIERI, R. V.; RAMOS, M. M. B.; CIESIELSKI, F. I. N.; SCHWEITZER, C. M. \& OKAMOTO, A. C. Antimicrobial activity of six plant extracts from the Brazilian savanna on periodontal pathogens. Int. J. Odontostomat., 5(3):249-256, 2011.

Monteiro, J. M.; de Albuquerque, U. P.; Lins-Neto, E. M.; de Araújo, E. L. \& Amorim, E. L. Use patterns and knowledge of medicinal species among two rural communities in Brazil's semi-arid northeastern region. J. Ethnopharmacol., 105:173-86, 2006.

Nagata, H.; Inagaki, Y.; Yamamoto, Y.; Maeda, K.; Kataoka, K.; Osawa, K. \& Shizukuishi, S. Inhibitory effects of macrocarpals on the biological activity of Porphyromonas gingivalis and other periodontopathic bacteria. Oral Microbiol. Immunol., 21:159-63, 2006.

Quirynen, M.; De Soete, M.; Boschmans, G.; Pauwels, M.; Coucke, W.; Teughels, W. \& van Steenberghe, D. Benefit of "on-stage full-mouth disinfection" is explained by disinfection and root planning within 24 hours: a randomized controlled trial. J. Clin. Periodontol., 33:63947, 2006.

Rao. V. S.; Viana, G. S.; Menezes, A. M. \& Gadelha, M. G. Studies on the antiulcerogenic activity of Astronium urundeuva Engl. II. Aqueous extract. Braz. J. Med. Biol. Res., 20:803-5, 1987.

Robertson, P. B.; del Aguila, M. A. \& Anderson, M. H. Trends in periodontal care. Periodontol. 2000, 30:104-10, 2002.

Rodriguez-Garcia, A.; Galan-Wong, L. J. \& Arevalo-Niño, K. Development and in vitro evaluation of biopolymers as a delivery system against periodontopathogen microorganisms. Acta Odontol. Latinoam., 23:158-63, 2010.

Sartoratto, A.; Machado, A. L. M.; Delarmelina, C.; Figueira, G. M.; Duarte, M. C. T. \& Rehder, V. L. G. Composition and antimicrobial activity of essential oils from aromatic plants used in Brazil. Braz. J. Microbiol., 35:275-80, 2004.

Singleton, S.; Treloar, R.; Warren, P.; Watson, G. K.; Hodgson, R. \& Allison, C. Methods for microscopic characterization of oral biofilms: analysis of colonization, microstructure, and molecular transport phenomena. Adv. Dent. Res., 11:133-49, 1997.

Tanner, A. C.; Kent, R. Jr.; Kanasi, E.; Lu, S. C.; Paster, B. J.; Sonis, S. T.; Murray, L. A. \& Van Dyke, T. E. Clinical characteristics and microbiota of progressing slight chronic periodontitis in adults. J. Clin. Periodontol., 34:917-30, 2007.
Correspondence to:

Elerson Gaetti Jardim Júnior

Department of Pathology and Oral Diagnostics

Universidade Estadual Paulista

R. José Bonifácio 1193, 16015-050

Araçatuba, São Paulo

BRAZIL

Tel. +55 18 3636-2797

Fax: +55 $183636-4125$

Email address: gaettijardim@gmail.com

Received: 14-10-2011

Accepted: 12-11-2011 